\section{Effect of Spraying with \\ 2,4-D upon Abundance of Pocket Gophers in Franklin Basin, Idaho ${ }^{1}$}

A. C. HULL, JR. ${ }^{2}$

Range Scientist, Crops Research Division, Agricultural Research Service, U.S. Department of Agriculture, Logan, Utah.

\section{Highlight}

Four $50 \times 50$ foot plots were sprayed with $2 \mathrm{lb}$./acre 2,4.D in 1959, 1960, 1965 and 1969 to kill fleshy-rooted, spring-growing plants and annuals. These plants are the major source of food for pocket gophers. Averaging the 10-year period, 1960-69, spraying reduced gopher mounds by $93 \%$ and winter casts by $94 \%$ when compared to the unsprayed areas.

Most investigators have found that fleshy roots and underground

${ }^{1}$ Cooperative investigations of Crops Research Division, Agricultural Research Scrvicc, U. S. Department of Agriculture; U. S. Forest Service, U. S. Department of Agriculture; and Utah Agricultural Experiment Station. Utah Agricultural Experiment Station Journal Paper 985. Received March 21, 1970; accepted for publication September 25, 1970.

${ }^{2}$ The author thanks those who assisted with the field phases of this work, and those who made helpful comments on the manuscript. Special thanks are due to Wesley and Arvel Bitters and Bernard Thurston, who did much of the field work. stems are the main food of pocket gophers (Moore and Reid, 1951; Garrison and Moore, 1956; Ward and Keith, 1962; Hansen and Ward, 1966). During the growing season, however, gophers prefer the above-ground parts of plants (Ward and Keith, 1962; Hansen and Ward, 1966).

Julander et al. (1969) suggest that reducing the food supply by herbicidal spraying may be a good method of reducing the number of pocket gophers. Keith et al. (1959), the Colorado Gopher Project (1960), and Hansen and Ward (1966) found that spraying a perennial forb range with 2,4-D in Colorado reduced the gopher population by $87 \%$ the year after spraying. They attributed the gopher decrease to a decrease in forbs which were their main source of food. Spraying temporarily increased grass production. In succeeding years as forbs increased and grass decreased on the sprayed area, the gophers increased. Reduced gopher numbers on sprayed areas was not from the toxicity of the herbicides, but the reduced food supply made treatcd areas unattractive to gophers.

Garrison and Moore (1956) found that good seedbed preparation which destroys broad-leaved herbs, renders new seeding sites unattractive to gophers. If this is also true on other range areas, then good seedbed preparation will not only help control gophers but will help insure successful range seedings by killing competing plants.

Gopher damage has often been severe on experimental seedings at Franklin Basin (Hull and Cox, 1968). Many experimental methods of seedbed preparation did not kill all fleshy-rooted plants and enough remained to induce gophers to remain on the seeded areas. This present study was to determine gopher activity over a 10 -year period on areas where fleshy-rooted perennial plants were controlled with 2,4-D.

\section{Procedures}

The experiment was conducted on an opening dominated by annual plants in the spruce-fir type in Franklin Basin in southeastern Idaho. The area is at 8,400 feet elevation and the annual precipitation averages 46 inches. Snow reaches a depth of 7 to 10 feet 


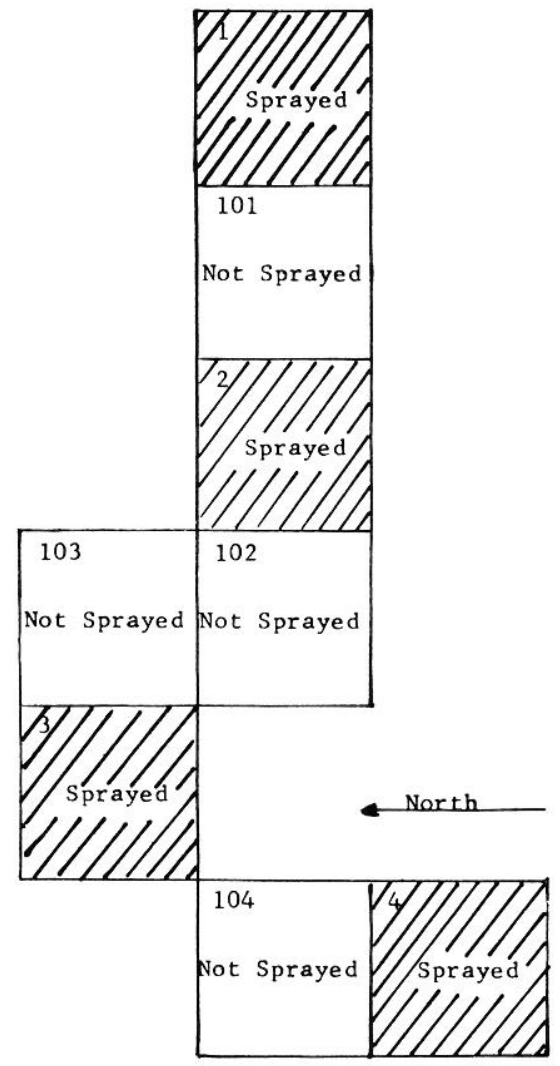

Fig. 1. Plot arrangement and treatments for the gopher study at Franklin Basin.

and normally covers the area from early November to early June.

The dominant species is cluster tarweed (Madia glomerata Hook.) with considerable bushy knotweed (Polygonum ramosissimum Michx.), collomia (Collomia linearis Nutt.), panicle willowweed (Epilobium paniculatum Nutt.), and lambstongue groundsel (Senecio integerrimus Nutt.).

In the spring there is a thick growth of fleshy-rooted plants such as lanceleaf spring beauty (Claytonia lanceolata Pursh), dogtooth violet (Erythronium grandiflorum Pursch), woodland star (Lithophragma tenella Nutt.), bicolor biscuitroot (Lomatium leptocarpum (Torr. and Gray) C. and R.), desert parsley (Lomatium grayi C. and R. and Lomatium nuttallii (A. Gray) Macbr.), Indian potato (Orogenia linearifolia $\mathrm{S}$. Wats.) and tuber starwort (Stellaria jamesiana Torr.).

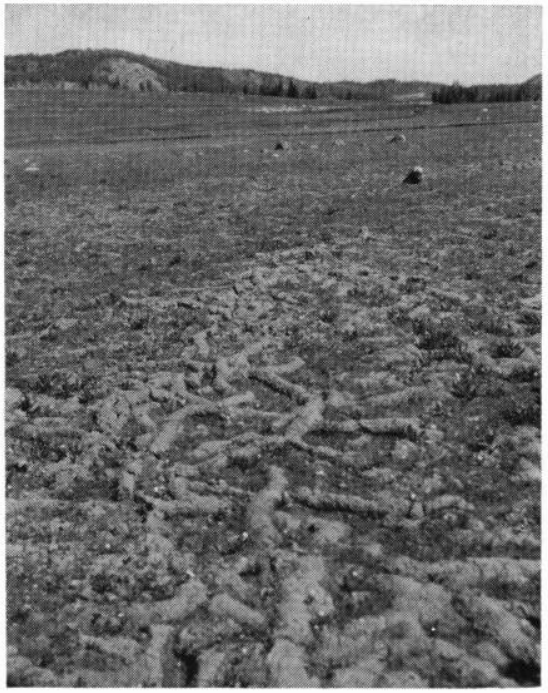

FIG. 2. Winter casts on an unsprayed area in the spring of 1970. This also is a general view of the study area.

The present vegetation, coupled with observations by early loggers and stockmen indicate heavy grazing, depletion of desirable vegetation, and soil loss on this area.

Eight plots, each $50 \times 50$ feet, were laid out to avoid large surface rocks (Fig. 1). Four of the plots were sprayed with $2 \mathrm{lb}$./acre of low-volatile ester of 2,4-D in the early spring of 1959. The only live vegetation after spraying was scattered plants of oniongrass (Melica bulbosa Geyer) and slender hairgrass (Deschampsia elongata (Hook.) Munro ex Benth.). Plots were sprayed again in 1960, 1965, and 1969 to control annual plants.

Winter casts and summer mounds of pocket gophers (Thomomys talpoides) were tabulated each October. Following counting, all plots were harrowed to destroy casts and mounds. Gopher mounds and casts varied by years. The highest was 1968 when unsprayed plots had 23 mounds and 77 feet of casts $/ 100 \mathrm{ft}^{2}$ (Fig. 2). The lowest was 1961 with 4 mounds and 14 feet of casts. Averaging the 10 years, spraying gave highly significant reductions of $93 \%$ in summer mounds and $94 \%$ in winter casts when compared to the unsprayed plots. As mounds are a good index of gopher populations (Keith et al., 1959; Richens, 1965; Hansen and Ward, 1966; and Reid et al., 1966), gopher numbers were undoubtedly similarly reduced (Table 1). There was no indication that 2,4-D was toxic to gophers, but rather that gophers found that an area with no food was an undesirable place to live.

Gopher food caches at Franklin Basin are mainly underground stems of spring-growing, fleshyrooted plants (Fig. 3). Spraying with 2,4-D killed these food plants, and there was then little gopher activity on the sprayed plots. There was no sprayed strip or buffer zone around sprayed plots, and the casts and mounds were usually just inside the edge of the plot. Observations showed no increase in gopher activity on the unsprayed plots when compared to surrounding unsprayed areas.

Within the exclosure where this study is located, there are many experimental grass and legume mixtures which have been seeded by many different methods each year from 1957 to the present. Where spraying with 2,4-D or machine seedbed preparation killed

Table 1. Linear feet of winter casts and number of summer mounds of pocket gophers per $100 \mathrm{ft}^{2}$. Average and range for the 10-year period, 1960-1969, at Franklin Basin. Differences between sprayed and not sprayed are significant at the $1 \%$ level.

\begin{tabular}{lccccc}
\hline \hline & \multicolumn{2}{c}{ Sprayed } & & \multicolumn{2}{c}{ Not sprayed } \\
\cline { 2 - 3 } \cline { 6 - 7 } & Avg. & Range & & Avg. & Range \\
\hline Winter casts & 2 & $1-4$ & & 32 & $8-77$ \\
Summer mounds & 1 & $.1-3$ & & 15 & $4-23$ \\
\hline
\end{tabular}




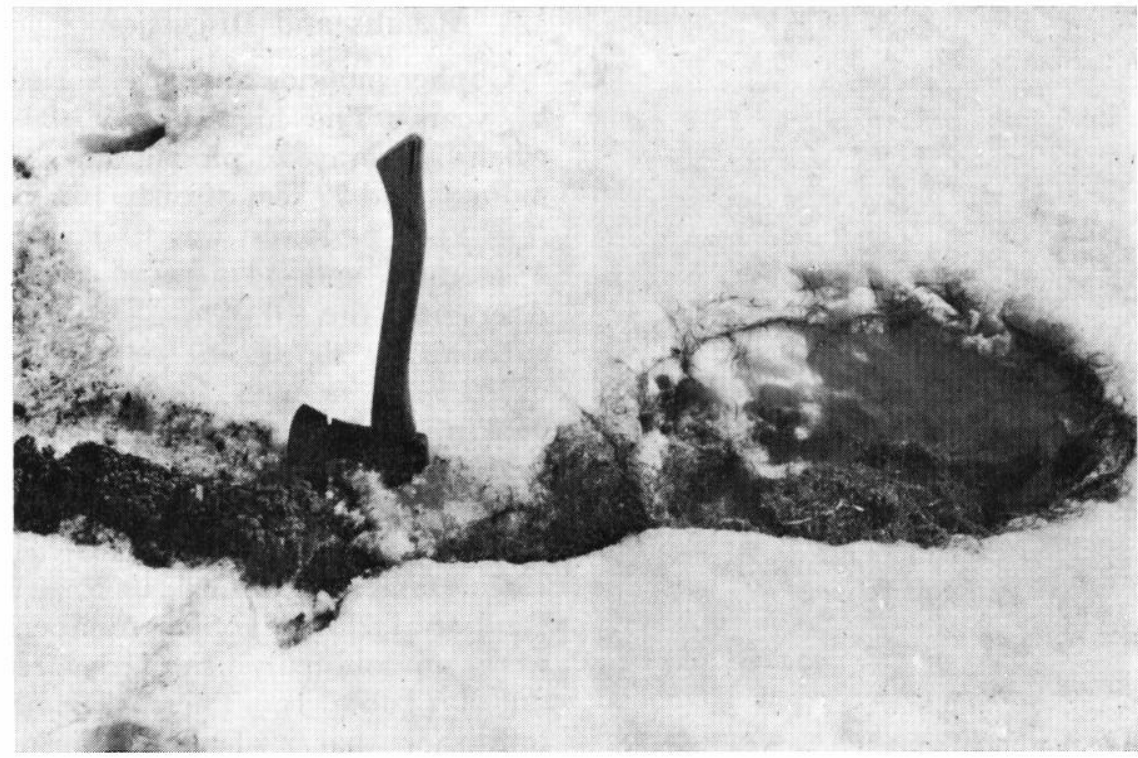

FIG. 3. Winter casts and food storage of fleshy roots in snow 20 inches above ground level in 1962.

the vegetation and where a good stand of seeded species resulted, gophers have done little damage to the seeded stands. Gophers eat some of the crowns during the winter and cut above-ground parts for nesting materials, but over a 12-year period this has not reduced yields of seeded stands. Major plants in these mixtures are: Smooth brome (Bromus inermis Leyss.), timothy (Phleum pratense L.), meadow foxtail (Alopecurus pratensis L.), tall oatgrass (Arrhenatherum elatius (L.) Presl.), and orchard grass (Dactylis glomerata L.).
Where seedbed preparation did not destroy the fleshy-rooted species, gophers have remained on the area and damaged the seeded stands. Also the native plants not killed during seedbed preparation have been severe competition for the seeded plants. Thus, good control of fleshy-rooted species not only reduced gopher populations but also killed plants which would compete with new seedings.

\section{Literature Cited}

Colorado State University. 1960. Pocket gophers in Colorado. Colo. Exp. Sta. Bull. 508-S. 26 p.
Garrison, George A., and A. W. MOORE. 1956. Relation of the Dalles pocket gopher to establishment and maintenance of range grass plantings. J. Range Manage. 9:181-184.

Hansen, R. M., AND A. L. WARd. 1966. Some relations of pocket gophers to rangelands on Grand Mesa, Colorado. Colo. Exp. Sta. Tech. Bull. 88. $22 \mathrm{p}$.

Hull, A. C., JR., and Hallie Cox. 1968. Spraying and seeding high elevation rangelands. J. Range Manage. 21:140-44.

Julander, Odell, Jessop B. Low, and OWen D. Morris. 1969. Pocket gophers on seeded Utah mountain range. J. Range Manage. 22:325329.

Keith, James O., Richard M. Hansen, AND LORIN A. WARD. 1959. Effect of 2,4-D on abundance and foods of pocket gophers. J. Wildlife Manage. 23:137-145.

Moore, A. W., and Elbert H. Reid. 1951. The Dalles pocket gopher and its influence on forage production of Oregon mountain meadows. U.S. Dep. Agr. Circ. No. 884 . 36 p.

Reid, V. H., R. M. HANSEN, AND A. L. WARD. 1966. Counting mounds and earth plugs to census mountain pocket gophers. J. Wildlife Manage. 30:327-334.

Richens, V. B. 1965. An evaluation of control on the Wasatch pocket gopher. J. Wildlife Manage. 29:413425.

Ward, A. Lorin, and James O. Keith. 1962. Feeding habits of pocket gophers in mountain grasslands, Black Mesa, Colorado, Ecology 43: 744-749.

\section{Nominations for the SRM Outstanding Accomplishment and Service Award}

This award is granted annually by the Society to one or more individuals whose careers or contributions to the science and art of range management have become eminently noteworthy. It may be presented to Society members or to persons from outside the Society who have rendered distinguished service.

Any person who has contributed significantly to the conservation and management of rangeland resources is eligible for consideration, except that members of the Board of Directors or Awards Committee are not eligible while serving in such positions.
A person may be nominated for the award by two or more members in good standing. Nominations should be typed on plain paper and contain the following information:

1. Name and address of nominee

2. Brief biography of nominee, including

(a) place and date of birth

(b) education and training

(c) professional positions and responsibilities

(d) previous awards and honors

(e) membership and activity in other societies and organizations

(f) service to SRM
3. Summary statement on importance of nominee's accomplishments and contributions to range management, including publications and activities

4. Names, addresses, and signatures of nominators.

The Awards Committee will consider all complete and valid nominations, but may also consider other worthy persons. Nominations should be received by the committee no later than June 30, 1971. They should be sent directly to Melvin S. Morris, University of Montana, Missoula, Montana 59801. 